\title{
硫黃を含む製鍊煙灰の爆発性にういで（I)
}

\author{
正会員木 内 俊 二** \\ On the Explosibility of Sulphurous Flue-dust
}

\section{Shunji KIUCHI}

- In this country, the flue-dust of copper smelters always includes more or less elementary sulphur besides combined sulphur as a result of adoption of pyritic smelting principle. Such flue-dust may have explosibility which is increased in strength with the increase of sulphur content.

Actual accidents of explosion have been reported in several places. For the purpose of preventing those accidents, the auther has been studying about the explosibility of both actual and synthetic sulphureous dust. By the explosion diagram proposed by the auther, it is possible to divide the field into two ranges, the explosion and nonexplosion range, by the amount of elementary sulphur.

If the sulphur content is less than about $20 \%$, the dust has no explosibility even at the presence of inflammables. Therefore, if we can limit the sulphure content under $20 \%$, there will be no explosion any more, fortunately, the above limit of sulphur, less than $20 \%$, can be maintained in the actual operation without great difficulty.

\section{1. 緒}

\section{言}

銅製鍊によつて生ずる唒灰中には，遊離状態の硫黄が 相当に含まれていることは，從来行われた諸所の分析結 果に徵して明らかである。しかして，かくの如き含硫黄 煙灰のある物は，爆発性を有することもまた從来の実験 並びに経験上よく知られた所である。著者は，この種の 爆発による現場の災害を防止する見地から，含硫黄粉塵 の爆発性を実験的に研究して来た。突際に煙道より得ら れた煙灰を硫黃の着火点直上の溫度 $\left(280^{\circ} \sim 300^{\circ} \mathrm{C}\right)$ に加 熱して遊離硫黃のすべてを一旦除去した後, 再度新しく 硫黄粉末を混合することによつて種々の硫黄舍有量の橪 灰を作り，この硫黄含有量と爆発下限との関係を求める と，硫黄量の減少と共に濑次に爆発下限が上昇し，つい にある量にまで硫黄か減少与ると爆発下限は無限大とな る。これを爆発の組成限界と名ずけると，この組成限界 以下の硫黄量の試料は，その着火源の下では，むはや爆 発性を持九ないこととなる。この関係艺著者は先に爆発 線図と名ずけて発表し，感応コイル（電源 $4 \mathrm{~V})$ 党使用し た弱、火花に上る着火に执いては爆発組成限界は硫黄量 約25\%であることを郝告し，これをもつて爆発の予防指

* 昭和 28 年 5 月11日受理

** 資源技術試驗所 第二部長
針の一助とし，から爆発時の状況判断に対しては有益な 資料を提供するであろう事を述べた。

爆発下限は着火源の强弱によつて異なつた值を示すこ とはすでに策験上明らかにされている。例えば L.J. Trostel 及び H. W. Frevert 等によれば第1表の如く であつて，灼熱コイルによる場合が最低の下限を示し， 硫黃の場合には他の着火源の場合の約牛分になつてい る。この懪発下限の䇅動にともなつて, 組成限界がどの 程度に変動するものであるかは大いに害験者の興味をそ そる問題であるのみならず，また実地に爆発線罒を利用 するに当つて, 是非共必要な條件である。よつて, 强大な

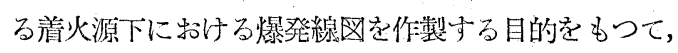
".

種々の着火源による爆発下限 $(\mathrm{mg} / \mathrm{l})$

(Trostel \& Frevert による)

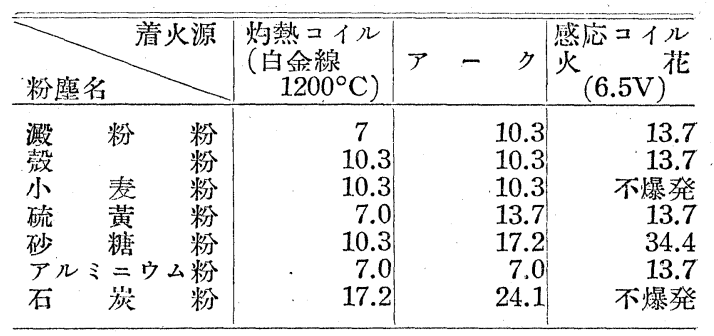


赤熱したニクロム線コイルを着火源として，実験を行つ たのであるが，その結果は直接に事故防止並びに操業上 の参考となると考えるのでここに発表する次第である。

\section{2. 実験方法及び実験結果}

\section{1. 裝置}

本容験に使用した裝置は，Trostel 等の用いたものと ほほ同一であつて，その主要部分は第1四に示すような 直径約 $180 \mathrm{~mm}$ の硝子製球状爆発容㗊からなる。粉雲体 生成のために球內底部の容器にあらかじめ粉磨を入れて 和きこれにノズルを通して瞬時圧風を吹きつけるよらに

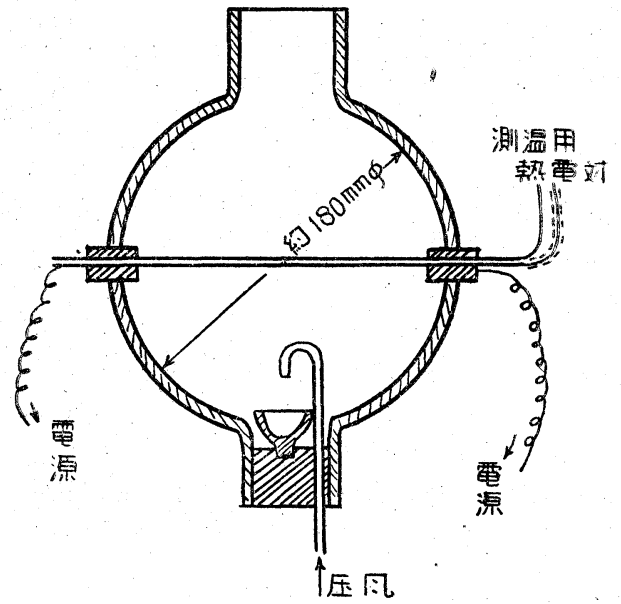

第 1 図 Clement Trazer 式爆発容器

なつている。球內中央に着火源を備えてあるが，これに は著者が適宜原型に变更を加えてある。すなわち，前回 の感応コイルによる火花放電に代えるに直径 $6 \mathrm{~mm}$ の磁 製管に直径 $0.5 \mathrm{~mm}$ の =クロム線を約 $1 \mathrm{~mm}$ 間隔に 20 回任 ど卷きつけたものを用い，その溫度は磁製管內に熱電対 を聥入して二クロム線コイルの中央を測定し，溫度を $700^{\circ} \mathrm{C}$ とて笑験した。

爆発の判定は從来着火によつて発生した焔の状態によ つて行つている場合が多く，この為に上記の硝子製爆発 容器が極めて好都合なのであるが，本塞験では焔が不明 確であつたので，簡学に，かるくしめた上部の栓が跳び 上る事によつて判定した。焰が良好伝播をなす最低粉鹿 濃度に㧧いては発生圧力思つた程大ではないから，上 記の制定結果は他の場合と大体比較可能と考元る。

\section{2. 煙灰試料}

試料の作製は前回に行つた感応コイル火花の場合と全 く同一に, $280^{\circ} \sim 300^{\circ} \mathrm{C}$ 加熱してすでに存在する遊鹤 硫黄を除き，これに新しく硫黄粉末を源加した。添加し た硫黄は -300 メッュで，デシケーターに貯蔵して乾 燥したものである。煙灰の分析は第 2 表の如きものであ るが，一般に煙灰の組成は製鍊所によつて或程度晎なる
第 2 表，煙灰分析（未燒）

\begin{tabular}{c|c|c|c|c|c}
\hline $\mathrm{Cu}$ & $\mathrm{Pb}$ & $\mathrm{Zn}$ & $\mathrm{Fe}$ & $\mathrm{As}$ & 残部 \\
\hline 1.22 & 9.04 & 7.74 & 3.06 & 1.66 & 硫黃及化物等 \\
\hline
\end{tabular}

のみならず，同一製鍊所に拮いても常に組成の变動を示 しているものであるから，この影響子当然考它ねばなり ないが，これについては別に述べるから，ここには遊離 硫黃以外の成分に関する限り，影響は著しいものではな いことのみ导述べておく。したがつてまた㖶灰は上記の 加熱に際して遊離硫黃を除去されるだけでなく，煙灰自 らも多少の変化をらけることは避けられないわけでする か，それに基く影響必爆発線园の実用上無就して差支之 ない。

\section{3. 験結果}

第2 困に実駼結果を示した。困中 印は 2 3 回の実 験において，全回爆発を示した位置でせり，×印は全回 不爆発を示した所である。本図によれば，硫黃約20\%辺 （嚴密には18\%）に爆発組成限界があり，これより硫黄 が少ないと相当强い着火源によつても爆発を示さないこ とになる。感応コイルの火花による場合を再錄すれいは心，

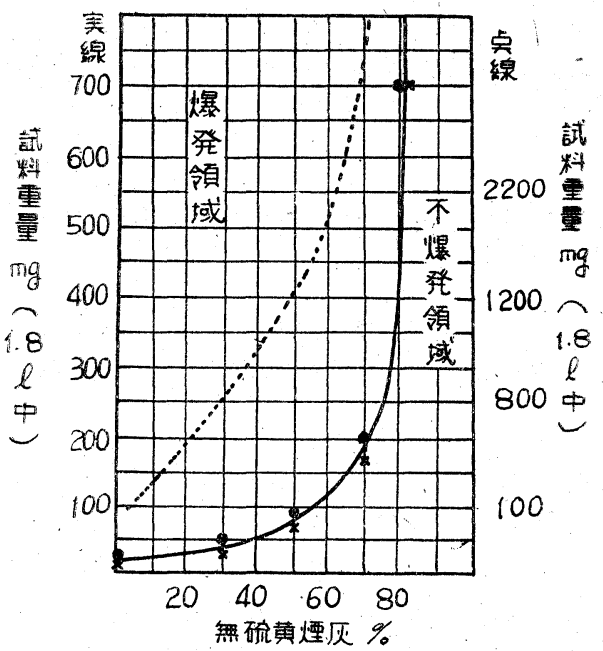

第2 図煙灰の爆発線図

$$
\begin{aligned}
& - \\
& \cdots \cdots \\
& \cdots \cdots
\end{aligned}
$$

同図点線の如くであつて，硫黄の減少と共に爆発下限は 急激に上昇して行くのである。本実験はこれに比して各 各の爆発下限が渚しく下つているのみならず，硫黄の減 少による上昇率が，はじめの間は極めて小さく，ために 爆発領域は著しく㢬大されていることが目立つ。しかし ながら，爆発の組成限界は僅かに数％の美を示したに渦 ぎず，のみならず限界も前者より明瞭に現われて来た。 両者を綜合して，爆発下限の変動は顕著であるが，組成 限界の変動は僅かであると考えられ，この点が災害防止 
上特に注目を要するのである。

\section{3. 爆発組成限界上実際作業との関係}

上記の爆発線困によれば，煙灰中の硫黄か爆発組成限 界以下になるように操業できるならば，簡単に煙灰の爆 発事故をなくすことが可能である。問題は，実操業に拉 いてこの限界がどの程度に守れるかといら点に眊つてい る。もし守ることに著しい困難を件う．ものであれば，折 角爆発組成限界を出して無意味であつて，爆発予防の ためには安全弁を附するとか，煙道中の酸素量を $9 \%$ 以 下に保つとか或いは煙道等の掃除の回数を增して，一定 量以上蓄積させ奴ようにするとかいう他の方策に全面 的に賴らねばならなくなる。しかるに彷来の煙灰の分析 例をみるに幸いにもこの限界の遵守は難しいことではな く，大部分の㖶灰はいずれる硫黄量が低くて不爆発領域 に属するものである。最近の各所の分析例を借用してみ ると第 3 表の如く，化合硫黄を含めた全硫黄加喲 $20 \%$ 位 そなつている。爆発に与るものは遊離硫黃であつて，上 の値より $5 \%$ から $10 \%$ 位低く，大体 $10 \%$ ふら $15 \%$ 位已推 定されるのであり，これは明確に不爆発性煙灰である。 不幸にしてもし爆発が起れば，それは全く例外的な場合 であつて，普通の場合より遊離硫黄が多量に含まれてい たそ断言しらるのである。

第3 表 最近の熛灰实例

\begin{tabular}{|c|c|c|c|c|c|c|c|c|c|}
\hline & 種 & 類 & $\mathrm{Cu}$ & $\mathrm{Pb}$ & $\mathrm{Zn}$ & $\mathrm{Fe}$ & $\mathrm{SiO}_{2}$ & As & $\mathrm{S}$ \\
\hline 1 & 熔 & & & $\begin{array}{r}7.89 \\
800\end{array}$ & 14.55 & $\begin{array}{l}15.36 \\
\end{array}$ & 4.14 & & 18.56 \\
\hline$?$ & $!$ & A & $\begin{array}{l}7.26 \\
0.32\end{array}$ & $\begin{array}{r}8.88 \\
3150\end{array}$ & $\begin{array}{r}6.95 \\
2\end{array}$ & 13.33 & & 6.24 & 20.46 \\
\hline & & $B$ & 0.32 & 31.50 & 34.30 & 0.64 & & & 6.77 \\
\hline & & & & 10 & & 18 & & & 19. \\
\hline 5 & " & 1 & 1.66 & 25.85 & 15.99 & 2.13 & 2.06 & & 18.38 \\
\hline
\end{tabular}

試みに第 3 表の煙灰に新しく硫黄粉末を混合してその 爆発性を2ると第 4 表の如くになる。これによると，こ れ等の煙灰乃爆発するまでには，硫黃量において，10〜 $15 \%$ 余晞があり，大体の見当として，全硫黄（化合硫 黄を含めて）が20\%までまず安全と考えてよからう。

第4 表 㗏灰が爆発するまでの添加硫黃量

\begin{tabular}{r|r|r|r|r|r}
\hline \hline 煙灰中 & \multicolumn{3}{|c|}{ 添 加 } & \multicolumn{1}{|c|}{ 硫 黃 } \\
\hline 硫黃量 & & $5 \%$ & $10 \%$ & $15 \%$ & $20 \%$ \\
\hline 18.56 & 3 & 不爆発 & 不爆発 & 不爆発 & 爆 発 \\
\hline 19.41 & 3 & 不暴発 & 不爆発 & 爆 & \\
\hline
\end{tabular}

\section{4. 煫火源に関する考察}

着火源の强弱によつて爆発下限は大きく，爆発組成限 界は僅少ながら影響を受けることは上に述べた通りであ る。粉雲体力瀑発するに際しては，(1) 粉歴に着火する
ための高溫熱源が存在すること，(2)着火した粉塵の燃 燒熱力゙隣接粉鷹の着火に必要な熱を供給すること，(3) それがために単位容積中の粉䵇量蜮限界以上に濃厚な ること等が充足されなくてはならない。の仮定に基ず いて, George Jaeckel は爆発條件として次式を提出し ている。

$$
\begin{aligned}
& p \cdot q \geqq V+(T-t)\left(p c_{2}+s c_{1}\right) \cdot \\
& p: \text { 粉雲体中の汾磨量, } \mathrm{g} / \mathrm{cm}^{3} \\
& q \text { : 粉鷹の燃燒熱, } \mathrm{cal} / \mathrm{g} \\
& V \text { : 伝導，輻射に上る熱損失, } \mathrm{cal} / \mathrm{cm}^{3} \\
& T^{\prime} \text { : 粉㘍の着火溫度 } \\
& t: \text { 粉磨の最初の溫度 } \\
& s: \text { 空気の密度, } \mathrm{g} / \mathrm{cm}^{3} \\
& c_{2} \text { : 粉鷹の比熱, } \mathrm{cal} / \mathrm{g}^{\circ} \mathrm{C} \\
& c_{1} \text { : 空気の恒容比熱 }(=0.17) \mathrm{cal} / \mathrm{g}^{\circ} \mathrm{C}
\end{aligned}
$$

故に上式を等式として $p$ にいて解けば，与なるち爆 発下限を与えるわけである。すなわち

$$
p=\frac{(T-t) s_{1} \cdot c_{1}}{q-(T-t) \cdot c_{2}}+\frac{V}{q-(T-t) c_{2}}
$$

$V=0$ ，すなわち熱損失がない場合は最も爆発條件が 理想化された場合であつて計算もまた容易であるが， Jaeckel は着火溫度 $410^{\circ} \mathrm{C}$ の砂糖粉について計算して 実験とよく合致しな値の得られることを記している。

硫黃粉の場合, 气の着火溫度は $280^{\circ} \mathrm{C}$ と されているが，115ㄷにおいて熔融する ことを考慮すれば爆発條件は次の如くにな る。

$$
\begin{aligned}
p \cdot q \geqq & +(280-t) s c_{1} \\
& +(115-t) p c_{2}+L \cdot p \\
& +(280-115) p c_{3} \cdots \cdots
\end{aligned}
$$

\section{ここに $c_{3}$ : 愹融硫黄の比熱}

$$
l: \text { 硫堊の熔融潜熱 }
$$$$
q: \text { 硫黄の発熱量 }
$$

である。これより爆発下限としての $p$ は

$$
\begin{aligned}
p & =\frac{(280-t) s c_{1}+V}{q-(115-t) c_{2}-L-(280-115) c_{3}} \cdots(4) \\
\text { いま } \quad V & =0, t=10, c_{1}=0.17, \quad s=0.00125, \quad \dot{q}=2121, \\
c_{2} & =0.18, \quad L=9, c_{3}=0.28
\end{aligned}
$$

とすれば

$$
p=0.000028 \mathrm{~g} / \mathrm{cm}^{3}
$$

を得る。

すなわち, 爆発下限は容積 $1 l$ 中において， $28 \mathrm{mg}$ と なる。これを上記の実験結果と比較してみると，大休咑 数は合つているが，その数值は感応コイルの火花による 場合に比して小さく，また，灼熱ニクロム線コイルによ る場合よりは大きな値となつている。顧るに，V=0な る條件は状況を理想化した場合にのみ考元られることで 
あつて，一般には満足せられていないのである。よつ て，pに実験値を代大し，V民求めてみると次のよ 5 に なる。

感応コイルの火花による場合，

$p=0.00005 \mathrm{~g} / \mathrm{cm}^{3}$ として $V=0.045$

赤熱ニクロム線による場合，

$p=0.00002 \mathrm{~g} / \mathrm{cm}^{3}$ そして $V=-0.017$

すなわち，前者においては明らかに熱損失がみられる が，後者においては符号が汉対になつている所から，熱 は逆に発生しているわけである。この熱の発生は勿論赤 熱されたニク口ム線に由来するものであつて，この場合 といえど为熱損失が存在するではあろろが，熱源が强大 なるために熱源からの供給熱か損失熱を淩駕七ているの であろら。これに対し前者は熱源が弱小であるためにそ の供給熱が損失熱に及ばず，したがつて全体としても熱 の損失を示寸結果となつているのである。はじめに，漠 然と，感応コイルの火花を弱い着火源とし，ニクロム線 の場合を强い着火源と呼んだのであるが，ここにはじめ てその理由が明瞭になつたわけである。Vは嚴密に考元 れば0ではないが，その值は左程大きなものではないこ とはこの実験並びに計算から認得るであろう。しかる にこれが単一可燃粉塵でなくて，不燃狌粉㦄が混合せら れるとVが次第に霄加するのであるが，これについては 後に述べる方が適当と考壳るので省略する。

さて，一応 $V=0$ なる理想化された場合について， (4)式により，室溫の影響を調べてみよう。(4)式に必 要な数値を代入して簡単にすれば,

$$
p=\frac{0.17(280-t) \mathrm{S}}{2066-(115-t)(0.18)}
$$

これに $t$ 及びSを与えて計算すれば第 5 表となるので めつて，爆発下限は大体室溫の上昇に刘して直線的に下 降するものである。强大なる着火源の場合に爆発下限が 計算值より低い事害に対する理由は既述の如くである が，本表に示された結果もその一因をなするのである。

なお，ここに使用したJaeckel の式深芫全反応の想定

第 5 表，室溫々爆発下限ののbとに，簡単に発熱量と 関係 $(V=0$ の場合)

\begin{tabular}{|c|c|c|}
\hline$t \begin{array}{c}\text { (室溫) } \\
\left({ }^{\circ} \mathrm{C}\right)\end{array}$ & $\mid$\begin{tabular}{|c|}
$S$ (空気 \\
の比熱)
\end{tabular} & $\begin{array}{l}p(\text { 爆発 } \\
\text { 限) } \\
(\mathrm{mg} / \mathrm{l})\end{array}$ \\
\hline 0 & 1.29 & 30 \\
\hline 10 & $\begin{array}{l}1.25 \\
\end{array}$ & 28 \\
\hline 20 & $\begin{array}{l}1.20 \\
\end{array}$ & 26 \\
\hline 40 & $\begin{array}{l}1.13 \\
\end{array}$ & 22 \\
\hline 60 & $\begin{array}{l}1.06 \\
\end{array}$ & 19 \\
\hline 80 & 1.00 & 16 \\
\hline 100 & 0.75 & 11 \\
\hline
\end{tabular}

吸等量の関係定示したるの であつて, 反庆論的洘察は 全く含まれていない。この 不供にかんがみ，最近，疋 田敎授は反応論の立場から 炭㗔爆発に抢音限界條件 式を誘導している。同式は 理諭的に筋を通したもので ある反面，定数を含み，直

ちに本稿に適用しにくく，かつその詳細にふれることは 本諭交の趣旨から逸脫するので，遺憾ながら述べなから た。

\section{5. 結語}

（1）硫黃を含有寸る粉塵は，弱火源のもとでは言5ま でもなく, 强い着火源のもとにおいても不発組成をも ち，之の限界が大体，硫黄20\%と考穴られる。この限 界は実際の操業上にさして困難なく守れるものである からこの点に留意して, 煙灰の爆発事故を防止するこ とが望ましい方法の一つと考える。

（2）爆発下限孛計算して，計算値と実験值を比較し， 着火源の强弱並びに窅溫の变化による爆発下限の変化 を考察した。

\section{参 考 文 献}

1) 著者: 茨城大学工学部研究集派 4 卷 1 号 $69-74$

2) " $"$ " 4 突 2 号

3) Trostel \& Frevert: Chem. Metall. Eng. 30. (1924). 141

4) G. Jaeckel: Z. Ver. Dtsch. Zuck-Ind. 73 (1923) 117

G. Jaeckel: Z. tech. phy. 5 (1924). S67.

P. Beyersdorfer: Stanb-Explosionen. (1925). 54.

5）疋田：工業火薬学会誌 11 笑 3 号 p. 156.

\section{技術叢書}

第5 輯 $($ 冶金 2 )

製鍊廃ガスの收塺と

稀薄亞硫酸ガスの捕收

A 5 判 200頁 280 円

第 7 輯（選銨 2 ）

重液選鉱

A 5 判 230 頁 250 円， $=40$ 円

第 9 輯（選鉱 3 )
管
(子)
w)
A 5 判 230頁 350円 $=40$ 円

日本鉱業会編

$$
\text { ニッケルをコバルト }
$$

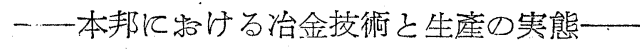

A 5 制上製 150頁 250 円 